\title{
Complexation to Cationic Microspheres of Double-Stranded Peptide Nucleic Acid-DNA Chimeras Exhibiting Decoy Activity
}

\author{
Carlo Mischiati $^{a}$ Alessia Sereni $^{a}$ Alessia Finotti ${ }^{a}$ Laura Breda ${ }^{a}$ \\ Rita Cortesi ${ }^{b}$ Claudio Nastruzzic Alessandra Romanellid Michele Saviano ${ }^{d}$ \\ Nicoletta Bianchia Carlo Pedone ${ }^{d}$ Monica Borgatti ${ }^{a}$ Roberto Gambaria,e \\ Departments of aiochemistry and Molecular Biology and 'bharmaceutical Sciences, University of Ferrara, Ferrara, \\ cDepartment of Pharmaceutical Chemistry and Technology, University of Perugia, Perugia, dinstitute of Biostructure

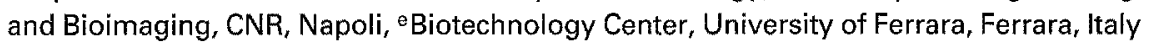

\section{Key Words}

Peptide nucleic acid-DNA chimeras - Microspheres .

Gene therapy

\begin{abstract}
The major aim of this paper was to determine whether cationic microspheres (CM), consisting of the permeable polymer Eudragit ${ }^{\circledast}$ RS 100 plus the cationic surfactant dioctadecyl-dimethyl-ammonium bromide $\left(\mathrm{DDAB}_{18}\right)$, could bind to double-stranded peptide nucleic acid PNADNA-PNA (PDP) chimeras exhibiting decoy activity against NF-KB transcription factors. Microspheres were produced by the 'solvent evaporation method' and centrifugation at 500, 1,000 and 3,000 rpm to obtain different-sized microparticles. Microsphere morphology, size and size distribution were determined by optical and electron microscopy observations. In order to determine their binding activity, double-stranded DNA-based and PDP-based decoy molecules were incubated with different amounts of microparticles in the presence of $100 \mathrm{ng}$ of either ${ }^{32} \mathrm{P}$-labeled DNA-DNA or DNA-PDP hybrid molecules or cold PDP-PDP hybrids. The complexes were analyzed by agarose gel electrophoresis. The resistance of ${ }^{32}$ P-labeled DNA-DNA and DNA-PDP molecules in the
\end{abstract}

\section{KARGER}

$\mathrm{Fax}+41613061234$ E-Mail karger@karger.ch www.karger.com (c) 2004 National Science Council, ROC

S. Karger AG, Basel

$1021-7770 / 04 / 0115-0697 \$ 21.00 / 0$

Accessible online at:

www. karger.com/jbs presence of serum or cellular extracts was evaluated after binding to $\mathrm{CM}$ by gel electrophoresis analysis. DDAB $_{18}$ Eudragit RS 100 microspheres are able to bind to DNA-PDP and PDP-PDP hybrids, to deliver these molecules to target cells and to protect DNA-PDP molecules from enzymatic degradation in simulated biological fluids. In addition, when assayed in ex vivo conditions, $\mathrm{DDAB}_{18}$ Eudragit RS 100 microspheres exhibited low toxicity. The results presented in this paper demonstrate that $\mathrm{CM}$ can be considered suitable formulations for pharmacogenomic therapy employing double-stranded PDP chimeras.

Copyright 2004 National Science Council, ROC and S. Karger AG, Base

\section{Introduction}

The transcription factor decoy (TFD) approach has been recently described as a very useful strategy to modify gene expression in the experimental treatment of human pathologies $[1,6,14,16,19,22,30]$. For instance, NF-кB decoy oligodeoxynucleotides have been used as agents in acute rejection and graft arteriopathy in cardiac transplantation [16]. Furthermore, Spl decoy oligodeoxynucleotides targeting regulatory elements of urokinase-type 
plasminogen activator inhibit cancer metastasis [14]. Reviews on applications of the TFD approach to nonviral gene therapy are available in the recent literature $[1,6,16$, 22]. One of the major problems of TFD is the degradation of DNA-based decoy molecules in serum and cellular extracts [17]. Therefore, DNA analogues resistant to exoand endonucleases are of great interest [15].

In this respect, peptide nucleic acids (PNAs) are molecules of great interest for possible application in pharmacogenetic therapy [20]. PNAs are based on a pseudopeptide (polyamide) backbone consisting of $\mathrm{N}$-(2-aminoethyl)glycine units $[13,20]$. Therefore, PNAs exhibit (1) the capacity to hybridize with high affinity to complementary sequences of single-stranded RNA and DNA, forming Watson-Crick double helices [20], and (2) resistance to DNAses and proteinases [8]. However, it should be emphasized that PNA oligomers are characterized by a negligible TFD activity and low solubility [13]. In addition, PNAs are not suitable to be complexed to cationic liposomes or microspheres since, being neutral molecules, they cannot form electrostatic interactions with these positively charged systems [24].

With respect to the possible application of PNA-based molecules in gene therapy, PNA-DNA-PNA (PDP) chimeras deserve great consideration $[2,23]$, due to the fact that they exhibit high levels of solubility and are expected to be resistant to proteinases and exonucleases [13]. In addition, we have recently reported that double-stranded PDP chimeras are powerful decoy molecules [3, 23]. We synthesized and analyzed a double-stranded PDP chimera mimicking the NF-KB binding sites of the HIV-1 long terminal repeat [23]. These molecules were found to be an excellent decoy for p52 and p50 NF- $\mathrm{kB}$ transcription factors.

In this study, we determined whether cationic microspheres (CM), consisting of the permeable polymer Eudragit $^{\text {B }}$ RS 100 plus the cationic surfactant dioctadecyldimethyl-ammonium bromide $\left(\mathrm{DDAB}_{18}\right)$ [9-11], could bind to PDP chimeras exhibiting decoy activity against NF- $\mathrm{KB}$ transcription factors.

Microparticles could offer a number of advantages compared to other delivery systems, such as liposomes, since they maintain unaltered chemicophysical properties for a long period of time, allowing long-term storage, and are expected to exhibit low toxicity [10]. In addition, depending on their composition, they could be administered through different routes (oral, intramuscular or subcutaneous). Finally, they are suitable for industrial production [10].

\section{Materials and Methods}

Synthetic Oligonucleotides and Production of NF-KB PNA-DNA Chimeras

Figure 1 shows the sequences of the produced PDP chimeras carrying binding sites for the transcription factors belonging to the NF- $\mathrm{BB}$ superfamily. NF- $\mathrm{kB}$ DNA-DNA was the reference decoy molecule, while PDP-DNA and PDP-PDP were the PNA-based decoy molecules analyzed in the present paper with respect to biological activity and complexation to liposomes.

The synthetic oligonucleotides used in this study were purchased from Sigma (St. Louis, Mo., USA). PNA monomers for production of PNA-DNA chimeras were synthesized in Prof. Van Boom's laboratories [27, 28] (Leiden Institute of Chemistry, Gorlaeus Laboratories, Leiden University, The Netherlands). DNA monomers were obtained from Perseptive Biosystems. Methanol (Rathburn, HPLC grade) was stored over molecular sieves $(3 \AA$ ) and used without other purification. All the other solvents (Biosolve DNA synthesis grade) were used as received. Automated syntheses of the chimeras were performed on a Pharmacia Gene Assembler, using highly crosslinked polystyrene (loading $26-28 \mu \mathrm{mol} / \mathrm{g}$ ) as the solid support on a $1-\mu \mathrm{mol}$ scale, as reported elsewhere [23]. After the last elongation step, the oligomers were cleaved from the solid support and deprotected by treatment with $1.5 \mathrm{ml}$ of methanolic ammonia at $50^{\circ} \mathrm{C}$ for $16 \mathrm{~h}$. The samples were filtered and then purified by RP-HPLC on a LiChrosphere $100 \mathrm{RP}-18$ end-capped column $(4 \times 250 \mathrm{~mm})$ on a Jasco HPLC system. Gradient elution was performed at $40^{\circ} \mathrm{C}$, building up the gradient starting with buffer $\mathrm{A}(50 \mathrm{~m} M$ triethylammonium acetate in water) and then applying buffer $B(50 \mathrm{~m} M$ triethylammonium acetate in acetonitrile-water, $1 / 1, \mathrm{v} / \mathrm{v}$, with a flow rate of $1 \mathrm{ml} /$ min). Chimera 1: HPLC purity $100 \%, t_{R}=18 \mathrm{~min}$ (gradient $3-20 \% \mathrm{~B}$ in $25 \mathrm{~min}$ ); chimera 2: HPLC purity $100 \%, \mathrm{t}_{\mathrm{R}}=16 \mathrm{~min}$ (gradient $5-25 \% \mathrm{~B}$ in $25 \mathrm{~min}$ ). HPLC-MS analysis was carried out on a Jasco LCMS system equipped with a LiChrosphere $100 \mathrm{RP}-18$ end-capped column $(4 \times 250 \mathrm{~mm})$ using a gradient of acetonitrile in $10 \mathrm{mM}$ ammonium acetate buffer with mass detection on a Perkin Elmer Sciex API 165 equipped with an Electrospray Interface (ESI). Chimera $1: t_{R}=7$ min (gradient $5-20 \%$ acetonitrile in $29 \mathrm{~min}$ ); ESI-MS: $[\mathrm{M}+4 \mathrm{H}]^{4+}=1,438.2,[\mathrm{M}+5 \mathrm{H}]^{5+}=1,150.5$, calculated for $\mathrm{C}_{193} \mathrm{H}_{245} \mathrm{~N}_{90} \mathrm{O}_{95} \mathrm{P}_{13} 5,748.26$. Chimera 2: $\mathrm{t}_{\mathrm{R}}=8 \mathrm{~min}$ (gradient $0-20 \%$ acetonitrile in $20 \mathrm{~min}$ ); ESI-MS: $[\mathrm{M}+4 \mathrm{H}]^{4+}=1,443.6,[\mathrm{M}+5 \mathrm{H}]^{5+}=$ 1,154.9, calculated for $\mathrm{C}_{194} \mathrm{H}_{247} \mathrm{~N}_{86} \mathrm{O}_{99} \mathrm{P}_{13} 5,770.26$.

Sequences: chimera 1: Gly-ccg-5'TGGAAAGTCCCCA3 ${ }^{\prime}$-gcg-Ac; chimera 2: Gly-cgc-5'TGGGGACTTTCCA3'-cgg-Ac.

\section{Production of Cationic Microparticles}

The polymer used for microparticle preparation was the acrylic resin Eudragit RS 100 from Rohm Pharma (Darmstadt, Germany). The cationic surfactant $\mathrm{DDAB}_{18}$ was from Fluka (Buchs, Switzerland). Microparticles were produced by the 'solvent evaporation method' as described in detail elsewhere [11]. Briefly, $500 \mathrm{mg}$ of a 100:30 (w/w) complex of Eudragit RS 100 and $\mathrm{DDAB}_{18}$ were dissolved in $5 \mathrm{ml}$ of $\mathrm{CH}_{2} \mathrm{Cl}_{2}$. The solution was emulsified with $100 \mathrm{ml}$ of an aqueous phase containing $1 \%(\mathrm{w} / \mathrm{v})$ of $88 \%$ hydrolyzed polyvinyl alcohol (Airvol 205, Air Products, Pa., USA) as dispersing agent (Ika Labortechnick, Germany). After complete evaporation of $\mathrm{CH}_{2} \mathrm{Cl}_{2}$, microparticles were isolated by centrifugation at $500,1,000$ and $3,000 \mathrm{rpm}$. Microparticle morphology, size and size distribution were determined by optical and electron microscopy observations as described elsewhere [11]. 


\begin{tabular}{|c|c|}
\hline $\begin{array}{l}\text { 5'-CGCTGGGGACTTTCCACGG-3' } \\
\text { 3'-GCGACCCCTGAAAGGTGCC-5' }^{\prime}\end{array}$ & $\begin{array}{l}\text { DNA-DNA } \\
\text { hybrid }\end{array}$ \\
\hline $\begin{array}{l}\mathrm{NH}_{2} \text { - Gly-CGC-5'-TGGGGACTTTCCA-3'-CGG-Ae } \\
\text { Ae-GCG-3'-ACCCCTGAAAGGT-3'-GCC-GlyNH } 2\end{array}$ & $\begin{array}{l}\text { PDP-PDP } \\
\text { hybrid }\end{array}$ \\
\hline $\begin{array}{l}5^{\prime} \text {-CGC TGGGGACTTTCCA CGG-3' } \\
\text { Ac-GCG-3'-ACCCCTGAAAGGT-5'-GCC-Gly-NII }\end{array}$ & $\begin{array}{l}\text { DNA-PDP } \\
\text { hybrid }\end{array}$ \\
\hline
\end{tabular}

Fig. 1. Structure and sequences of the decoy molecules used in this study, based on DNA or PDP chimeras. The sequences are recognized by transcription factors belonging to the NF- $\kappa B$ family. DNA segment spans from $5^{\prime}$ - to $3^{\prime}$-termini. The protocol for the synthesis of PNA oligomers on a 1- $\mu \mathrm{mol}$ scale has been described elsewhere.

\section{Complexation of NF-KB DNA-DNA, DNA-PDP and PDP-PDP}

\section{Hybrids to Microspheres}

Different amounts of microparticles were incubated in the presence of $100 \mathrm{ng}$ of either ${ }^{32} \mathrm{P}$-labeled DNA-DNA or DNA-PDP hybrid molecules or cold PDP-PDP. The complexes were electrophoresed through an agarose gel and exposed to an autoradiographic procedure (in the case of DNA-DNA and DNA-PDP molecules) or stained with ethidium bromide (in the case of PDP.PDP molecules) [23].

\section{Resistance of Decoy Molecules}

The resistance of ${ }^{32}$ P-labeled DNA-DNA and DNA-PDP target molecules was evaluated as follows. The decoy molecules were incubated without or with different amounts of microspheres (2-25 $\mu \mathrm{g} /$ reaction) for $30 \mathrm{~min}$ at room temperature, and then serum (fetal calf serum, Eurobio, France) was added ( $3 \mu \mathrm{l} /$ reaction). After overnight incubation, the reactions were phenol extracted, ethanol precipitated and electrophoresed through a polyacrylamide gel, and autoradiography was performed. Disappearance of the decoy molecule band was considered evidence of degradation by the employed enzymes [3].

We always premixed unlabeled PCR products or oligonucleotides just before phenol extraction in order to control the recovery.

\section{Cell Lines and Culture Conditions}

Human erythroleukemia K562(S) cells were cultured in a humidified atmosphere at $5 \% \mathrm{CO}_{2}$ in RPMI-1640 (Flow Laboratories) supplemented with $10 \%$ fetal bovine serum (CELBIO), 50 units $/ \mathrm{ml}$ penicillin and $50 \mu \mathrm{g} / \mathrm{ml}$ streptomycin. The effects of $\mathrm{DDAB}_{18}$ Eudragit RS 100 microspheres on in vitro cell growth were determined after 3 days by an MTT-based colorimetric assay. In order to determine the uptake of DNA-PDP chimeras in living cells, chimera 2 was annealed to an equal amount of the complementary 5 -fluoresceinlabeled DNA and, after $16 \mathrm{~h}$, the molecules were fractionated by electrophoresis onto a $10 \%$ polyacrylamide gel. Bands corresponding to the annealed DNA-PDP were electroeluted and concentrated by centrifugation onto microcon-3 tubes (Amicon, Millipore Corporation, Bedford, Mass., USA). Four hundred nanograms of DNA-PDP were incubated with $320 \mu \mathrm{g}$ of $\mathrm{DDAB}_{18}$ Eudragit RS 100 microspheres for $20 \mathrm{~min}$ in $\mathrm{PBS}$ at room temperature and, after this time, the mixture

\section{Eudragit RS : DDAB 18}
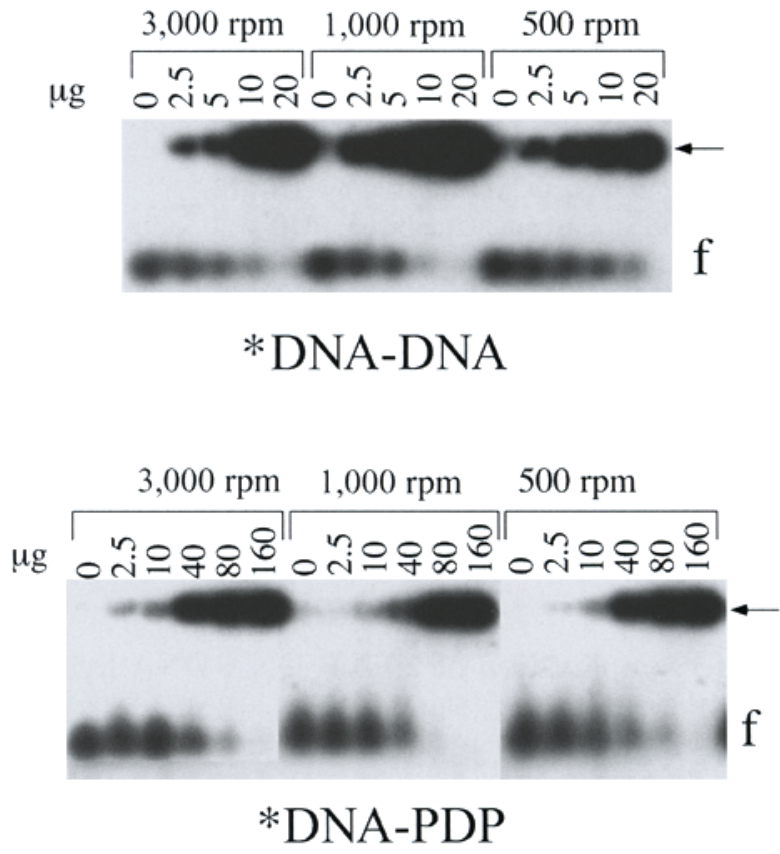

Fig. 2. Comparison of the complexation efficiencies of NF- $\mathrm{BB}$ DNADNA and NF-KB DNA-PDP hybrids to CM. The indicated amounts of microspheres were incubated in the presence of ${ }^{32} \mathrm{P}$-labeled DNADNA or DNA-PDP hybrid molecules, and complexes formed were fractionated by electrophoresis through an agarose gel and exposed to autoradiography. Arrows indicate material bound to microspheres. $\mathrm{f}=$ Free decoy molecules.

was added to $4 \mathrm{ml}$ of complete medium containing $1 \times 10^{6}$ cells. Aliquots of $1 \mathrm{ml}$ each were collected 2,8 and $24 \mathrm{~h}$ later, washed 3 times with PBS, spotted onto poly-lysine-coated microscope slides and fixed. Mounted slides were observed at $\times 2,000$ on an Olympus BX60 fluorescence microscope.

\section{Results}

\section{Complexation of Double-Stranded DNA-PNA Chimeras to Microspheres}

Figure 2 shows that CM bind to DNA-PDP hybrids. This is demonstrated by the formation, when high concentrations of CM were used (5-10 $\mu$ g/reaction), of complexes (identified as bound material) unable to migrate into the gels. It should be noted that complexation of NF- $k B$ DNA-PDP to microspheres is somewhat lower 
Fig. 3. a Binding of PDP-PDP molecules to increasing amounts of $\mathrm{CM}$ prepared by centrifugation at 3,000 rpm. Unlabeled PDPPDP hybrids (arrows) were detected by agarose gel electrophoresis and ethidium bromide staining. A representative experiment was reported. b Quantitative determination of free DNA-DNA (O) and PDP-PDP (O) hybrids after the addition of increasing amounts of $\mathrm{CM}$.

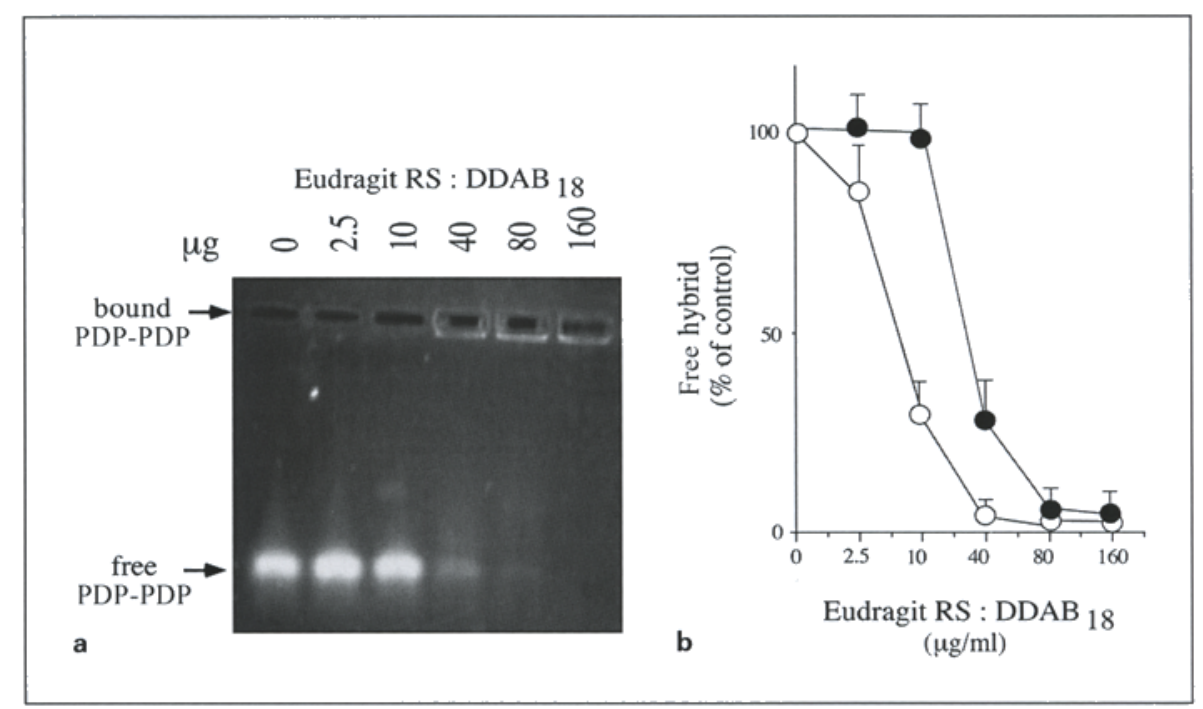

than the complexation of NF-kB DNA-DNA hybrids to this CM formulation. Furthermore, PDP-PDP hybrids efficiently bind to $\mathrm{CM}$ isolated by centrifugation at $3,000 \mathrm{rpm}$, even if showing binding affinity somewhat lower than that exhibited by DNA-DNA hybrids (fig. 3). In this case, due to the difficulty of obtaining ${ }^{32} \mathrm{P}$-labeled PDP-PDP chimeras, unlabeled PDP-PDP molecules were used and the gels were stained with ethidium bromide.

This finding allows us to propose microspheres for possible use in nonviral gene therapy for delivery of PDPbased molecules to target cells on the one hand and for the possible protection of PDP molecules in biological fluids after complexation with microspheres. This latter possibility is of great interest for in vivo delivery. Furthermore, protective effects in cellular extracts are also important as decoy molecules are expected to exert their effects only if sufficient stability allows their localization in the nuclear compartment. In light of these considerations, therefore, it is imperative to demonstrate (1) uptake by cultured cells and (2) possible protective effects in the presence of high amounts of serum and cellular extracts.

\section{Uptake of DNA-PDP Hybrids by Cultured K562 Cells}

In these experiments, fluorescein-labeled DNA was employed and annealed with complementary PDP chimeras. The hybrid double-stranded molecules (NF-kB DNA-PDP) were bound to an excess of $\mathrm{DDAB}_{18}$ Eudragit RS 100 microspheres $(3,000 \mathrm{rpm})$ and cultured for increasing lengths of time (2, 8 and $24 \mathrm{~h})$ with human leukemic K 562 cells. After 2 h, microspheres loaded with flu- orescein-labeled DNA-PDP NF- $\mathrm{kB}$ chimeras are visible as bodies attached to cells (fig. 4, upper panels). Interestingly, after $8 \mathrm{~h}$, the fluorescent molecules are visible in the cytoplasm (fig. 4 , middle panels), and after up to $24 \mathrm{~h}$, they are widely distributed into the cells (fig. 4 , lower panels). Fluorescein-labeled DNA-PDP molecules recovered after these experiments were found to maintain their double-stranded structure (data not shown).

\section{Protective Effects of Microspheres on Double-Stranded DNA-PNA Chimeras}

In order to verify whether the observed binding of PNA-based decoy molecules to CM leads to protective effects, the experiment illustrated in figure 5 was performed. In this experiment, DNA-PDP and DNA-DNA molecules were used, since PDP-PDP hybrids are resistant in serum and cellular extracts even in the absence of microspheres [5].

When ${ }^{32}$ P-labeled DNA-PDP chimeras or DNA-DNA molecules were incubated in serum overnight in the absence of microspheres, degradation of ${ }^{32} \mathrm{P}$-labeled DNA was observed (fig. 5, filled arrows). By contrast, when the DNA-PDP chimeras or DNA-DNA molecules were incubated with increasing amounts of CM $(20-140 \mu \mathrm{g})$, before the addition of serum (fig. 5, left panels) or cellular extracts (fig. 5, right panels), they were protected from degrading enzyme activity, and the size of recovered DNA (filled arrows in fig. 5) was identical to that of untreated molecules, showing that no enzymatic degradation of DNA-PDP molecules occurs after complexation to CM. Results similar to those shown in figure 5 were 


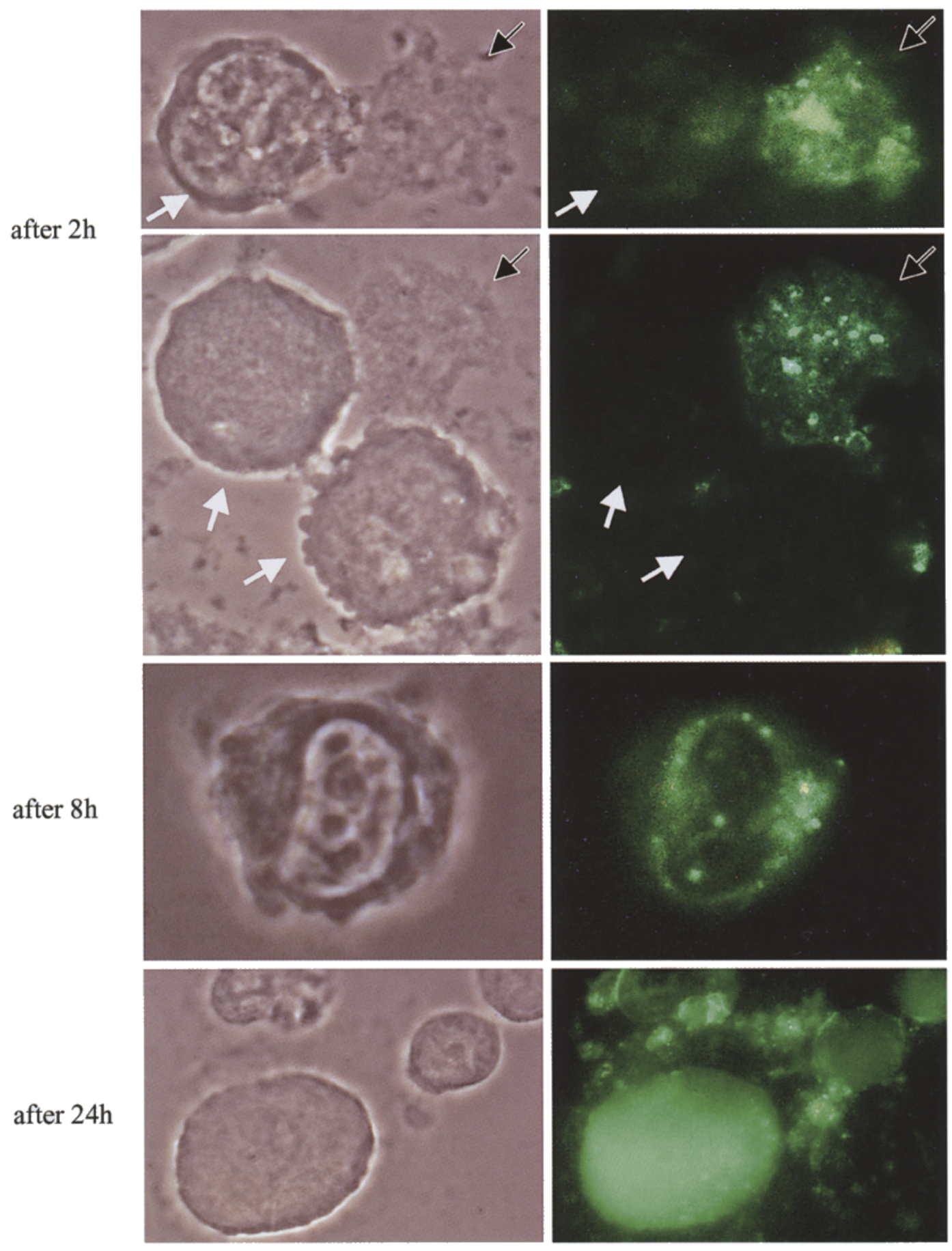

Fig. 4. Uptake of DNA-PDP chimeras in K562 cells. Fluorescein-labeled DNA-PDP hybrids were bound to $\mathrm{CM}$ prepared by centrifugation at $3,000 \mathrm{rpm}$. The complexes were added to the cells in culture medium and aliquots were collected after 2,8 and $24 \mathrm{~h}$. Representative fields from different time points are shown. Left panels: phase contrast. Right panels: fluorescence. Black arrows indicate the microspheres; white arrows indicate the cells. 
Fig- 5. Protective effects of CM, prepared by centrifugation at $3,000 \mathrm{rpm}$, on ${ }^{32} \mathrm{P}$-labeled NF- $\kappa$ B DNA-DNA and DNA-PDP target molecules. DNA-DNA and DNA-PDP target molecules were incubated without (w/o) $\mathrm{CM}$ or with increasing amounts (shown as $\mu \mathrm{g} /$ reaction) of $\mathrm{CM}$ for $30 \mathrm{~min}$ at room temperature, and then serum (left panels) or K562 cellular extracts (right panels) were added ( $3 \mu \mathrm{l} /$ reaction for serum and $1 \mu \mathrm{g} /$ reaction for cellular extracts). After an overnight incubation, the molecules were purified by phenol extraction and separated by electrophoresis on denaturing polyacrylamide gel. Filled arrows indicate the migration of intact DNA molecules.

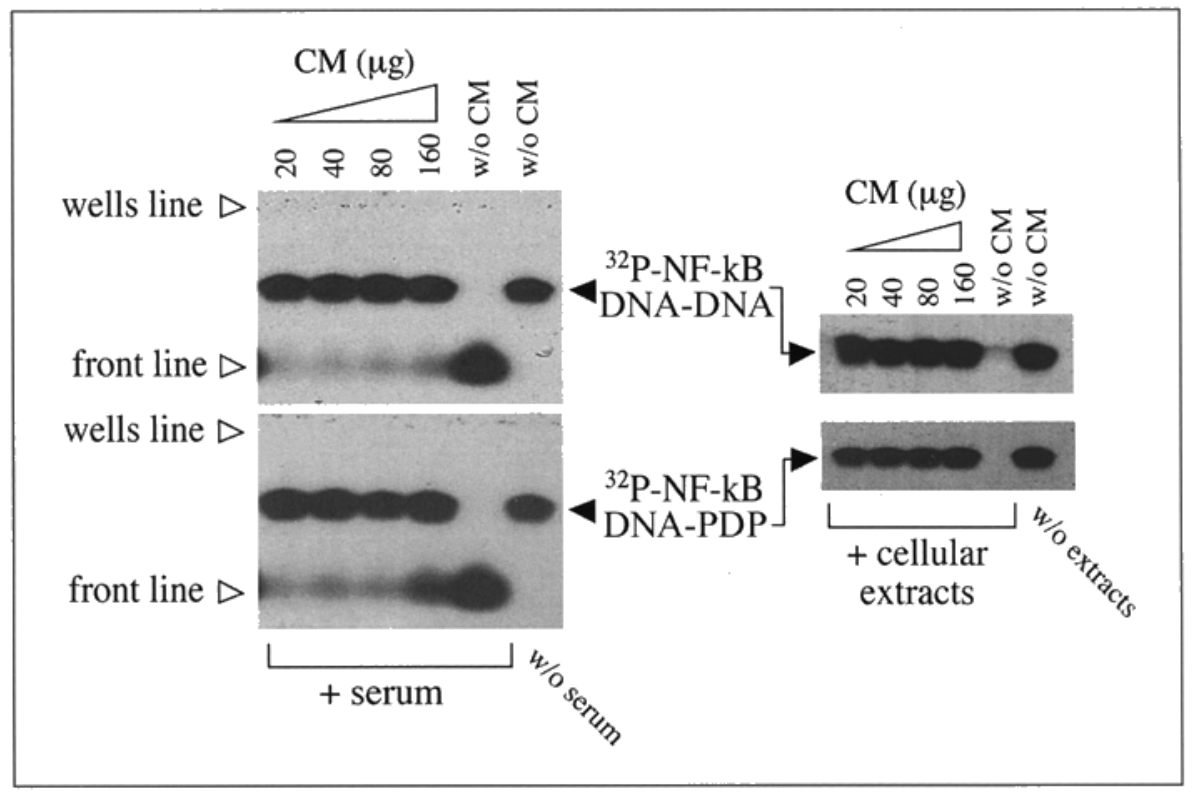

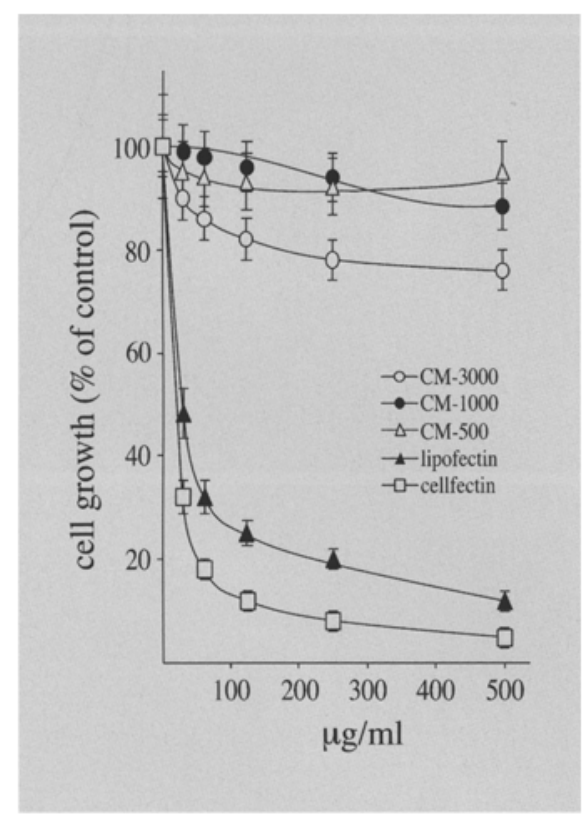

Fig. 6. Effects of microspheres on cell growth. K562 cells were cultured in the absence or in the presence of the indicated amounts of microspheres, separated by centrifugation at 3,000 rpm (CM-3000), $1,000 \mathrm{rpm}(\mathrm{CM}-1000)$ or $500 \mathrm{rpm}$ (CM-500), or common commercially available cationic lipids (lipofectin or cellfectin). After 3 days, the cell number $/ \mathrm{ml}$ was determined in treated cells and compared to that of control cells. obtained by repeating the experiments with commercially available enzymes (data not shown).

\section{Effects of CM on Cell Growth}

The effects of $\mathrm{CM}$ on ex vivo cell growth of the human leukemia K562 cell line were determined by an MTTbased colorimetric assay. In order to perform a comparison with commercial delivery systems for DNA, lipofectin and cellfectin were also included in the experiment. The results of the experiment are shown in figure 6 . As is clearly appreciable, a low antiproliferative effect was shown in the presence of CM. In contrast, it should be emphasized that lipofectin and cellfectin displayed a higher antiproliferative activity (fig. 6).

\section{Discussion}

In spite of the number of possible advantages over commonly used nucleic acids, PNAs present two major drawbacks: (1) being neutral molecules, they are not suitable for efficient delivery with nonviral cationic formulations (liposomes, dendrimers, polymers) [24], and (2) they are not useful for TFD therapy, one of the most interesting approaches to controlling gene expression $[4,7,13$, 18]. Interestingly, we have recently demonstrated that DNA-PNA hybrids carrying the HIV-1 long terminal repeat NF- $\mathrm{kB}$ binding site bind to the NF- $\mathrm{kB}$ factor purified or present within nuclear extracts, although the com- 
plex formed is only weakly stable [18]. In addition, we have demonstrated that PNA-DNA chimera hybrids interact with transcription factors $\mathrm{NF}-\mathrm{KB}$ and $\mathrm{Spl}$ in a stable manner $[4,23]$. Furthermore, PDP chimeras are resistant to exonucleases [13] and are active in inhibiting interactions between transcription factors and DNA [4, 5, 23, 24]. However, in order to improve cellular uptake and stability in biological fluids, an efficient strategy to deliver PNA-DNA chimeras is highly recommended.

With this aim, we set out to determine whether microspheres could efficiently bind to PNA-DNA chimeras exhibiting decoy activity. Instead of PNAs, which, being neutral molecules, are not suitable to be complexed to cationic liposomes or microspheres, we used PNA-DNA chimeras, which are charged molecules and could form electrostatic interactions with these positively charged systems.

The results presented in this paper demonstrate that CM of different sizes (fig. 2) bind to PNA-DNA chimeras with an efficiency comparable to DNA molecules (fig. 2,3) and thus represent a useful vehicle for the in vitro delivery of PDP-PDP and DNA-PDP decoy hybrids carrying NF- $\mathrm{KB}$ binding sites to target cells. In addition, $\mathrm{CM}$ were found to exhibit low cytotoxicity when compared to commercial liposome formulations (fig. 6) and to protect DNA-PDP hybrids from enzymatic degradation in biological fluids (fig. 5). This is a very important problem in gene therapy based on the use of DNA and DNA analogues $[31,33]$.

These results are clearly complementary to those already reported by our research group using liposomes as delivery systems [3]. It is to be emphasized that micropar- ticles and liposomes are complementary delivery systems. In fact, liposomes are excellent delivery systems in systemic treatments [26, 32]. On the other hand, microparticles, by reason of their larger dimensions $(30-300 \mu \mathrm{m})$, stability and high drug loading, are particularly useful for therapeutic approaches involving chemoembolization [2, 12] and subcutaneous implants [25]. Interestingly, both systemic and local administration routes for TFD molecules targeting NF- $\mathrm{KB}$ transcription factors are demanded. For instance, systemic administration of NF- $\mathrm{KB}$ decoy oligodeoxynucleotides reduces monocyte infiltration in renal allografts [29]. On the other hand, local administration of decoy molecules targeting NF- $\mathrm{KB}$ factors could be of great interest for experimental therapy of periodontitis or osteopenic diseases [21].

The results presented in this paper are thus of practical importance, since the simplicity and the versatility of $\mathrm{CM}$ technology has made these reagents useful nonviral gene delivery systems for human gene therapy [11]. In this respect, further studies are in progress in order to assess the ex vivo effectiveness of microspheres for PNA-DNA chimera administration.

\section{Acknowledgements}

This work was supported by the Associazione Veneta per la Lotta alla Talassemia, by CNR-P.F. Biotechnologie, by MURST-COFIN2002, by Finalized Research funds (year 2001) from the Italian Ministry of Health and by the AIRC. The technical assistance of Mr. Giuseppe Perretta is gratefully acknowledged. The authors wish to thank Prof. J.H. van Boom and J.C. Verhejien for allowing them to synthesize the chimeras in their laboratory.

\section{References}

1 Ahn JD, Morishita R, Kaneda Y, Lee KU, Park JY, Jeon YJ, Song HS, Lee IK. Transcription factor decoy for activator protein-1 (AP-1) inhibits high glucose- and angiotensin II-induced type 1 plasminogen activator inhibitor (PAI-1) gene expression in cultured human vascular smooth muscle cells. Diabetologia 44:713-720; 2001.

2 Ball DS, Heckman R, Olenick SW, Folander HL, Reed I 3rd. In vitro stability of tris-acryl gelatin microspheres in a multipharmaceutical chemoembolization solution. J Vasc Interv Radiol $14: 83-88 ; 2003$.
3 Borgatti M, Breda L, Cortesi R, Nastruzzi C, Romanelli A, Saviano M, Bianchi N, Mischiati C, Pedone C, Gambari R. Cationic liposomes as delivery systems for double-stranded peptide nucleic acid (PNA)-DNA chimeras exhibiting decoy activity against nuclear factor $-\mathrm{k} B$ transcription factors. Biochem Pharmacol 64: $609-616 ; 2002$.

4 Borgatti M, Lampronti I, Romanelli A, Pedone C, Saviano M, Bianchi N, Mischiati C, Gambari $R$. Transcription factor decoy molecules based on a peptide nucleic acid (PNA)-DNA chimera mimicking Sp1 binding sites. J Biol Chem 278:7500-7509;2003.

5 Borgatti M, Romanelli A, Saviano M, Pedone C, Lampronti I, Breda L, Nastruzzi C, Bianchi N, Mischiati C, Gambari R. Resistance of decoy PNA-DNA chimeras to enzymatic degradation in cellular extracts and serum. Oncol Res 13:279-287;2003.
6 Cho-Chung YS. CRE-palindrome oligonucleotide as a transcription factor decoy and an inhibitor of tumor growth. Antisense Nucleic Acid Drug Dev 8:167-170;1998.

7 Cho-Chung YS, Park YG, Nesterova M, Lee YN, Cho YS. CRE-decoy oligonucleotide-inhibition of gene expression and tumor growth. Mol Cell Biochem 212;29-34;2000.

8 Demidov VV, Potaman VN, Frank-Kamenetsk MD, Egholm M, Buchard O, Sonnichsen SI, Nielsen PE. Stability of peptide nucleic acids in human serum and cellular extracts. Biochem Pharmacol 48:1310-1313;1994.

9 Esposito E, Cortesi R, Luca G, Nastruzzi C. Pectin-based microspheres: A preformulatory study. Ann NY Acad Sci 944:160-179;2001. 
10 Esposito E, Roncarati R, Cortesi R, Cervellati F, Nastruzzi C. Production of Eudragit microparticles by spray-drying technique: Influence of experimental parameters on morphological and dimensional characteristics. Pharm Dev Technol 5:267-278;2000.

11 Esposito E, Sebben S, Cortesi R, Menegatti E, Nastruzzi C. Preparation and characterization of cationic microspheres for gene delivery. Int $\mathrm{J}$ Pharm 189:29-41;1999.

12 Furuse J, Ishii H, Satake M, Onaya H, Nose H, Mikami S, Sakai H, Mera K, Maru Y, Yoshino M. Pilot study of transcatheter arterial chemoembolization with degradable starch microspheres in patients with hepatocellular carcinoma. Am J Clin Oncol 26:159-164;2003.

13 Gambari R. Peptide nucleic acids (PNAs): A tool for the development of gene expression modifiers. Curr Pharm Des 7:1839-1862; 2001.

14 Ishibashi $H$, Nakagawa $K$, Onimaru M, Castellanous EJ, Kaneda Y, Nakashima $Y$, Shirasuna $\mathrm{K}$, Sueishi K. Spl decoy transfected to carcinoma cells suppresses the expression of vascular endothelial growth factor, transforming growth factor betal, and tissue factor and also cell growth and invasion activities. Cancer Res 60 : 6531-6536;2000.

15 Lebedeva I, Stein CA. Antisense oligonucleotides: Promise and reality. Annu Rev Pharmacol Toxicol 41:403-419;2001.

16 Mann MJ, Dzau VJ. Therapeutic applications of transcription factor decoy oligonucleotides. $\mathrm{J}$ Clin Invest 106:1071-1075;2000.

17 Meyer O, Kirpotin D, Hong K, Sternberg B, Park JW, Woodle MC, Papahadjopoulos D. Cationic liposomes coated with polyethylene glycol as carriers for oligonucleotides. J Biol Chem 273:15621-15627;1998.
18 Mischiati C, Borgatti M, Bianchi N, Rutigliano C, Tomassetti M, Feriotto G, Gambari R. Interaction of the human NF-kappaB p52 tranm scription factor with DNA-PNA hybrids mimicking the NF-kappaB binding sites of the human immunodeficiency virus type 1 promoter. J Biol Chem 274:33114-33122;1999.

19 Morishita R, Aokj M, Kaneda Y. Decoy oligodeoxynucleotides as novel cardiovascular drugs for cardiovascular disease. Ann NY Acad Sci 947:294-301;2001.

20 Nielsen PE, Egholm M, Berg RH, Buchardt $O$. Sequence-selective recognition of DNA by strand displacement with a thymine-substituted polyamide. Science 254:1497-1500; 1991.

21 Penolazzi L, Lambertini E, Borgatti M, Piva R, Cozzani M, Giovannini I, Naceari R, Siciliani G, Gambari R. Decoy oligodeoxynucleotides targeting NF-kappaB transcription factors: Induction of apoptosis in human primary osteoclasts. Biochem Pharmacol 66:1189-1198; 2003.

22 Piva R, Gambari R. Transeription factor decoy (TFD) in breast cancer research and treatment. Technol Cancer Res Treat 1:405-416;2002.

23 Romanelli A, Pedone C, Saviano M, Bianchi N, Borgatti M, Mischiati C, Gambari R. Molecular interactions between nuclear factor $\mathrm{kB}$ (NF-KB) transcription factors and a PNA-DNA chimera mimicking $\mathrm{NF}_{-} \mathrm{kB}$ binding sites. Eur $\mathrm{J}$ Biochem 268:1-11;2001.

24 Scarfi S, Giovine M, Gasparini A, Damonte $G$, Millo E, Pozzolini M, Benfatti U. Modified peptide nucleic acids are internalized in mouse macrophages RAW 264.7 and inhibit inducible nitric oxide synthase. FEBS Lett 451:264-268; 1999.

25 Shenoy DB, D'Souza RJ, Tiwari SB, Udupa N. Potential applications of polymeric microsphere suspension as subcutaneous depot for insulin. Drug Dev Ind Pharm 29:555-563; 2003.
26 Thomas SM, Zeng Q, Dyer KF, Suscovich TJ, Kanter PM, Whalen JD, Watkins SF, Grandis JR. Tissue distribution of liposome-mediated epidermal growth factor receptor antisense gene therapy. Cancer Gene Ther 10:518-528; 2003.

27 van der Laan AC, Meeuwenoord NJ, KuylYeheskiely E, Oosting RS, Brands R, yan Boom JH. Solid support synthesis of a PNADNA hybrid. Recl Trav Chim Pays Bas 114: 295-297; 1995.

28 Vinayak R, van der Laan AC, Brill R, Otteson $\mathrm{K}$, Andrus A, Kuyl-Yeheskiely E, van Boom $\mathrm{JH}$. Automated chemical synthesis of PNA and PNA-DNA chimera on a nucleic acid synthesizer. Nucleosides Nucleotides 16:1653-1656; 1997.

29 Vos IH, Govers R, Grone HJ, Kleij L, Schurink M, De Weger RA, Goldschmeding R, Rabelink TJ. NFkappaB decoy oligodeoxynucleotides reduce monocyte infiltration in renal allografts. FASEB J 14:815-822;2000.

30 Wang LH, Yang XY, Kirken $\mathrm{RA}_{*}$ Resau $\mathrm{JH}$, Farrar WL. Targeted disruption of STAT6 DNA binding activity by an oligonucleotide decoy blocks IL-4-driven $\mathrm{T}(\mathrm{H}) 2$ cell response. Blood 95:1249-1257;2000.

31 Wilber A, Lu M, Schneider MC. Deoxyribonuclease I-like III is an inducible macrophage barrier to liposomal transfection. Mol Ther 6:35$42 ; 2002$.

32 Xu L, Huang CC, Huang W, Tang WH, Rait A, Yin YZ, Cruz I, Xiang LM, Pirollo KF, Chang $\mathrm{EH}$. Systemic tumor-targeted gene delivery by anti-transferrin receptor scFv-immunoliposomes. Mol Cancer Ther 1:337-346;2002.

33 Yi SW, Yune TY, Kim TW, Chung H, Choi YW, Kwon IC, Lee EB, Jeang SY. A cationic lipid emulsion/DNA complex as a physically stable and serum-resistant gene delivery system. Pharm Res 17:314-320;2000. 